\title{
Molybdenum isotopic composition as a tracer for low-medium temperature hydrothermal ore-forming systems: A case study on the Dajiangping pyrite deposit, western Guangdong Province, China
}

\author{
SONG ShiMing ${ }^{1}$, HU Kai ${ }^{*}$, WEN HanJie ${ }^{2}$, ZHANG YuXu², LI Kuang ${ }^{3}$ \& FAN HaiFeng ${ }^{2}$ \\ ${ }^{1}$ State Key Laboratory for Mineral Deposits Research, School of Earth and Engineering, Nanjing University, Nanjing 210093, China; \\ ${ }^{2}$ State Key Laboratory of Ore Deposit Geochemistry, Institute of Geochemistry, Chinese Academy of Sciences, Guiyang 550002, China; \\ ${ }^{3}$ Wuxi Research Institute of Experimental Geology, SINOPEC Exploration and Production Research Institute, Wuxi 214000, China
}

Received January 30, 2011; accepted March 25, 2011

\begin{abstract}
Little is known about the range or controls on the molybdenum isotopic composition of low-medium temperature hydrothermal ore-forming systems. We present molybdenum isotope data from 12 hydrothermal syndepositional silicalite and carbonaceous slate samples from the Dajiangping pyrite deposit in western Guangdong Province, South China. The $\delta^{97 / 95}$ Mo values from Orebody III range from $-0.02 \%$ o to $0.29 \%$, with an average of $0.18 \%$ o. In contrast, the composition values from Orebody IV display a larger variation from $-0.70 \%$ to $0.62 \%$. However, the five samples from the main ore bed all show strong negative values. This indicates that the significant variation in molybdenum isotopic composition supports different hydrothermal ore-forming metallogenesis and a metallogenic environment between the two orebodies. Orebody III is likely to have been deposited from submarine exhalative hydrothermal fluids under a relatively strong reducing environment and Orebody IV may have also been influenced by hydrothermal superimposition in a more oxidized disequilibrium condition. In addition, the $\delta^{97 / 95}$ Mo values of Orebody IV are clearly negative, together with the values increasing stratigraphically upward in the ore beds, suggesting that the metallogenic environment of Orebody IV is different from the open oceanic systems. There might be dynamic fractionation in this restricted environment. Therefore, the molybdenum isotope can be used as an effective tracer for the ore-forming fluid and metallogenic environment.
\end{abstract}

molybdenum isotope, metallogenic environment, Dajiangping pyrite deposit

Citation: Song S M, Hu K, Wen H J, et al. Molybdenum isotopic composition as a tracer for low-medium temperature hydrothermal ore-forming systems: A case study on the Dajiangping pyrite deposit, western Guangdong Province, China. Chinese Sci Bull, 2011, 56: 2221-2228, doi: 10.1007/s11434-011-4536-6

The use of non-traditional stable isotopes (e.g. Mo, Fe, $\mathrm{Cu}$, $\mathrm{Zn}, \mathrm{Se}, \mathrm{Cr}$ ) has developed rapidly during recent years with Multiple Collector Inductively Coupled Plasma Mass Spectrometry (MC-ICP-MS) being increasingly used for their identification. In particular, molybdenum (Mo) isotopes have shown specific advantages in understanding redox conditions involved in modern sea, lake and other regional or local depositional environments, the geochemical evolution of paleo-oceanography and paleoclimatic changes [1-10]. Mo is the most abundant transition metal in the oceans with a concentration of $\sim 105 \mathrm{nmol} / \mathrm{kg}$ [11]. In mod-

*Corresponding author (email: kaihu@nju.edu.cn) ern oceans, Mo shows relatively conservative geochemical behavior with a residence time of 800 ka $[12,13]$. Hence, the geochemical behavior of Mo has global implications. Mo is a typical redox-sensitive element possessing IV, V, VI and other oxidation states. The isotopic fractionation of Mo depends strongly on its redox reactions. In oxygenated oceans, Mo exists mainly as the tetrahedral molybdate ion $\left(\mathrm{MoO}_{4}^{2-}\right)$ [3]. Mo fractionation depends predominantly on Fe-Mn oxide absorption $[3,14,15]$, and is restrained by the density of $\mathrm{H}_{2} \mathrm{~S}$ under anoxic or euxinic environments [16]. Hence, Mo and Mo isotopes can be used as a proxy to trace ocean systems in theory. However, few applications have 
been undertaken on its use in relatively complex mineral deposit geochemistry, especially the data and control of the molybdenum isotopic composition in hydrothermal oreforming systems. In general, several Mo isotopic data in high-temperature hydrothermal systems have been reported $[1,17,18]$, with little of low-medium hydrothermal oreforming systems. Therefore, studies on Mo isotopes and the Mo fractionation mechanism can provide useful information to understand the formation of hydrothermal deposits.

The formation of the deposits is controlled by multiple factors, including the ore-forming fluid temperature, concentration, redox conditions (Eh), $\mathrm{pH}$ and reaction rate of wall rock. The redox conditions of the metallogenic environment change and/or the interaction between the oreforming fluid and wall rock causing the redox state variation that lead to changes in compound solubility are important mechanisms in metal precipitation. Hence, the study on the ore-forming fluid and redox conditions of a metallogenic environment may have important significance. The wellknown Dajiangping super pyrite deposit located in western Guangdong Province of South China consists mainly of the massive Orebody IV and the banded Orebody III. Previous studies indicated that Orebody IV and III have different geochemical characteristics [19-26]. For example, the $\mathrm{Eu}$ value of Orebody IV is positive and its $\delta^{34} \mathrm{~S}$ sulfide values range from $12.60 \%$ o to $21.07 \%$, while Orebody III has a negative Eu value and its sulfide $\delta^{34} \mathrm{~S}$ values vary from $-25.55 \%$ o to $-15.52 \%$. Moreover, Orebody III contains more organic matter and radioactive lead. Hence these unambiguous differences may indicate that both of the ore-forming fluids and metallogenic environment between the two orebodies vary pronouncedly. In this paper, we use the Mo isotope as a novel tracer in the ore-forming fluid and metallogenic environment to provide new useful evidence for ore genesis.

\section{Geological setting and deposit description}

The Dajiangping pyrite deposit is located in the Yunfu metamorphic block mass, in western Guangdong Province of South China. Outcrop Sinian-Cambrian strata occur widely. The ore district has a deposit of a series of marine facies flysh and flyschoid with fine detrital stone formation. The basal stratum of the mining area consists of high-grade metamorphose garnet, amphibolite, gneiss and granulitite, and upward the basal stratum are epimetamorphic quartzite, schist interstratified phyllonite and partial limestone or hornstone. With respect to the ore-bearing strata, it is composed mainly of metamorphosed carbonaceous slate, carbonaceous siltstone, siliceous rock and siliceous limestone alternated with a banded pyrite layer. The silicalite is well-developed and is present as layers, a thin layer or a penecontemporaneous siliceous band, which occur inside or above the symbiosis pyrite orebody [23]. The top of the ore bed consists of siltstone, phyllite interlaminated limestone and tuff (Figure 1). A feature common to this pyrite deposit is that it is distributed in layer, tabular, lenticular styles, with consistent occurrence of the wall rocks and a gradual contact. In addition, banded ore beds and rhythmic layers can be observed, reflecting syn-depositional characteristics. There are five ore bodies with the main orebodies being the banded Orebody III and massive Orebody IV. The maximum thickness of Orebody IV is approximately $160 \mathrm{~m}$. The primary ore minerals are pyrite, together with relatively minor amounts of pyrrhotite, galena and sphalerite.

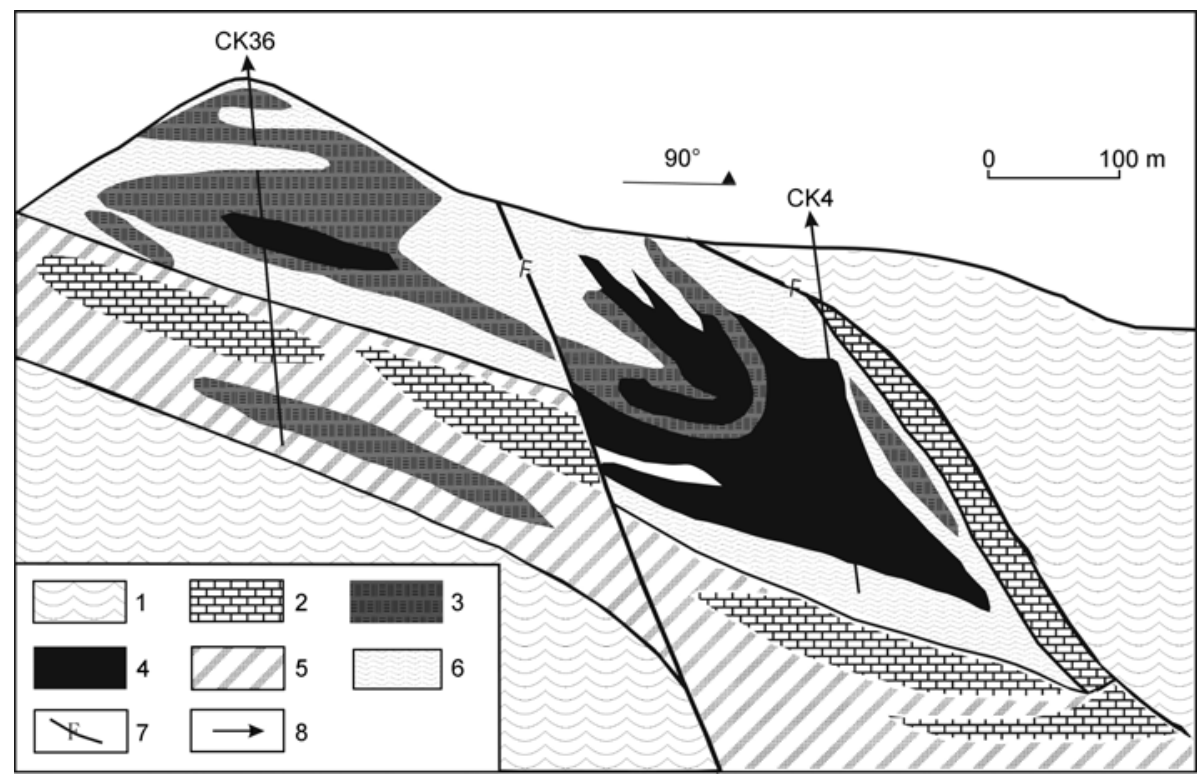

Figure 1 Schematic section of the Dajiangping pyrite deposit. 1, Clastic rock; 2, crystalline limestone, schist and quartzite; 3, Orebody III; 4, Orebody IV; 5 , quartite, schist and phyllite; 6 , carbonaceous slate and siltstone, silicalite and tuff; 7 , fault; 8 , prospecting line. 


\section{Sampling and analytical techniques}

According to previous studies, the siliceous rocks and orebody deposit syngenetically with hydrothermal water $[19-21,23,26]$. It is considered that the orebody has been subjected to anaphase hydrothermal alteration, mostly single colloidal minerals, and the pyrite was gelatinous containing impurities that could not be easily separated. We selected 12 typical samples, mostly syndepositional siliceous rocks, including two carbonaceous slate samples. All these samples are altered by ore-forming fluid, whose nature can hence be studied by analyses on the samples. In addition, some samples (e.g. Djp3-20 and Djp4-10) are ore whole-rock samples. An improved anion/cation exchange resin two-column procedure was used for Mo separation and purification. The detailed process has been described by Zhang et al. [27]. The Mo isotope ratios were measured using an Isoprobe MC-ICP-MS at CRPG in France. The "Sample-standard bracketing" method was employed to correct the mass bios in instrumental measurement and chemical separation. Two methods were used for data quality control. When dissolving the analyzed samples, each solution was collected before and after the subsequent chemical separation respectively for trace-element analyses. The overall recovery ratios and matrix removal effect were thus assessed. Under our current assessment, the recovered Mo yield was $97.49 \% \pm 0.27 \%$ and the matrix (such as major ions or molecules with heavy elements $\mathrm{Fe}, \mathrm{Mn}, \mathrm{Zr}, \mathrm{Ru}$ ) removal rate was close to $100 \%$, which indicated that it could be exclusive for the quality fractionation in the Chemical pre-treatment process as well as matrix effect in the process of mass spectrometry. Next, two internal Mo standards (SG-2 and S-3) were added in the chemical pre-treatment process and several parallel samples were also disposed of simultaneously by chemical treatment to monitor the circuit. Related data are listed in Table 1. Results are reliable and satisfied with the quality control criteria.

Table 1 Mo isotopic standard sample and repeated sample measured results $^{\text {a) }}(\% o)$

\begin{tabular}{ccc}
\hline Sample & $\begin{array}{c}\text { Reference value } \\
\left(\delta^{97 / 95} \mathrm{Mo}\right)\end{array}$ & $\begin{array}{c}\text { Measured value } \\
\left(\delta^{97 / 95} \mathrm{Mo}\right)\end{array}$ \\
\hline SG-3 & $-1.11 \pm 0.19$ & $-1.11 \pm 0.08$ \\
SG-2 & $0.96 \pm 0.26$ & $1.08 \pm 0.12$ \\
Djp4-16 & & $-0.36 \pm 0.10$ \\
Djp4-16 (repeated) & & $-0.41 \pm 0.24$ \\
\hline
\end{tabular}
[28]

a) The reference values of SG-2 and SG-3 are quoted from Wen et al.

Because there are few universally acknowledged Mo isotopic international standards, a latest calibrating NIST SRM 3134 solution recommend by Wen et al. [28] was used as an internal reference standard. Meanwhile, Wen et al. suggested that the current international internal isotope laboratory using various criteria, such as JMC, Merck, NIST SRM 3134, with its Mo isotopic composition is consistent within errors [28]. Therefore, the measured data in this paper can be compared with other reported data. The results here and literature data are expressed in the form of $\delta{ }^{97 / 95}$ Mo based on standard NIST SRM 3134. For the presentation of results, $\delta$-notation is utilized, as defined by the relationship:

$$
\begin{aligned}
\delta^{97 / 95} \mathrm{Mo}(\% o)= & {\left[\left({ }^{97} \mathrm{Mo} /{ }^{95} \mathrm{Mo}\right)_{\text {Sample }} /\left({ }^{97} \mathrm{Mo} /{ }^{95} \mathrm{Mo}\right)_{\mathrm{NIST}}-1\right] } \\
& \times 1000 \% \text { o }
\end{aligned}
$$

The $\mathrm{S}$ isotope ratios were measured using the Flash-EA MAT-253 mass spectrometer at the Resource and Environmental Engineering Center of East China Institute of Technology in Nanchang. The detailed processes are as follows: grind the mineral samples to 200 mesh, weigh out a $20-100$ $\mu \mathrm{g}$ sample and oxidize with $\mathrm{SO}_{2}$ at $1020^{\circ} \mathrm{C}$. The technical accuracy of $\delta^{34} \mathrm{~S}$ was less than $0.2 \%$.

Trace element analyses were performed on a Finnigan MAT Element HR-ICP-MS at the State Key Laboratory for Mineral Deposits Research, Nanjing University. The accuracy was better than $0.5 \times 10^{-9}$, with a relative standard deviation less than 5 .

\section{Results and discussion}

Analytical results are listed in Table 2. The $\delta^{97 / 95}$ Mo values vary from $-0.70 \%$ o to $0.62 \%$ per mil relative to the NIST SRM 134 Mo standard. The $\delta^{97 / 95}$ Mo values of Orebody III range from $-0.02 \%$ o to $0.29 \%$, with an average of $0.18 \%$ o $(n=3)$ with narrow variation. In contrast, the $\delta^{97 / 95}$ Mo values of Orebody IV show a different distribution trend compared with Orebody III. Particularly, the five samples from the main ore bed with strong negative values and the minimum value reaching $-0.70 \%$. The $\delta{ }^{97 / 95}$ Mo values still present obvious positive value at the upper part of the main ore bed with the maximum value of $0.62 \%$. The $\delta^{97 / 95} \mathrm{Mo}$ value of the surrounding rock sample (BP-3) collected from the fault belt between the two orebodies is $0.36 \%$, between the $\delta^{97 / 95}$ Mo values of Orebody III and IV. It is consistent with the other geochemical indications, such as organic matter content, $\mathrm{Pb}$ isotope and $\mathrm{He}-\mathrm{Ar}$ isotope [20-22,24], that the geochemical features of the fault belt lie between Orebody III and IV. Among the samples DJP3-12 and DJP3-20, DJP4-10 and CK4-05, $\delta^{97 / 95}$ Mo values of the carbonaceous slate are slightly higher than the homoeomerous chert in a relatively narrow range. The higher values of the carbonaceous slate, with partly silicified limestone or limestone as primary rocks, may be related to more synchronous heavy Mo isotopic seawater that are added into this layer during the formation period. Therefore, it indicates that the $\delta{ }^{97 / 95}$ Mo values in the carbonaceous slate and chert are 
Table 2 Analytical results of Mo and S isotope compositions in the Dajiangping pyrite deposit

\begin{tabular}{lcccrcr}
\hline Samples & Sampling location & Depth $(\mathrm{m})$ & Lithologic characters & \multicolumn{1}{c}{$\delta^{97 / 95} \mathrm{Mo}(\% \mathrm{o})$} & $\mathrm{Mo}(\mu \mathrm{g} / \mathrm{g})$ & $\delta^{34} \mathrm{~S}(\% \circ)$ \\
\hline BP-3 & fault (transition belt) & 145 & argillaceous silicalite & $0.36 \pm 0.08$ & 2.64 & -17.51 \\
CK36-08 & main ore bed of Orebody III & 105 & argillaceous silicalite & $-0.02 \pm 0.19$ & 5.49 & -10.95 \\
Djp3-12 & main ore bed of Orebody III & 130 & carbonaceous slate & $0.29 \pm 0.17$ & 6.28 & -12.01 \\
Djp3-20 & main ore bed of Orebody III & 140 & ore bearing silicalite & $0.27 \pm 0.06$ & 6.94 & -13.38 \\
CK4-05 & upper plate of Orebody IV & 110 & carbonaceous slate & $0.62 \pm 0.02$ & 9.01 & 3.24 \\
Djp4-10 & upper plate of Orebody IV & 130 & ore bearing silicalite & $0.60 \pm 0.09$ & 2.01 & -1.09 \\
Djp4-16 & main ore bed of Orebody IV & 160 & ore bearing silicalite & $-0.36 \pm 0.10$ & 1.77 & -1.44 \\
Djp4-7 & main ore bed of Orebody IV & 180 & silicalite & $-0.70 \pm 0.24$ & 1.64 & -8.99 \\
Djp4-9 & main ore bed of Orebody IV & 180 & silicalite & $-0.59 \pm 0.04$ & 1.95 & 2.60 \\
CK4-13 & main ore bed of Orebody IV & 210 & silicalite & $-0.34 \pm 0.05$ & 2.49 & -1.42 \\
CK4-17 & main ore bed of Orebody IV & 230 & carbonaceous silicalite & $-0.09 \pm 0.06$ & 2.05 & 3.09 \\
CK4-22 & orebody IV floor & 260 & carbonaceous slate with & $0.04 \pm 0.16$ & 3.14 & 22.69 \\
\hline
\end{tabular}

controlled mainly by the metallogenic environment with little relation to the lithology. With respect to $\mathrm{S}$ isotopes, remarkable difference between the two orebodies is also showed. The $\delta^{34} \mathrm{~S}$ values in Orebody III are negative in a relatively narrow range, indicating the influence of biogenic sulfur. In contrast, the $\delta^{34} \mathrm{~S}$ values from Orebody IV have a relatively broad range from $-11.44 \%$ o to $22.69 \%$, suggesting more complex ore-forming fluids. This is similar to the understanding from $\delta{ }^{97 / 95}$ Mo values.

Figure 2 presents a comparison of Mo isotopic compositions between the current study and those in natural samples, including the values of the reported Archean and Proterozoic black shale, modern submarine sediments and some hydrothermal synthesis molybdenite. Different from the Archean or Proterozoic black shales and modern submarine anoxic sediments, the Mo isotopic composition from the

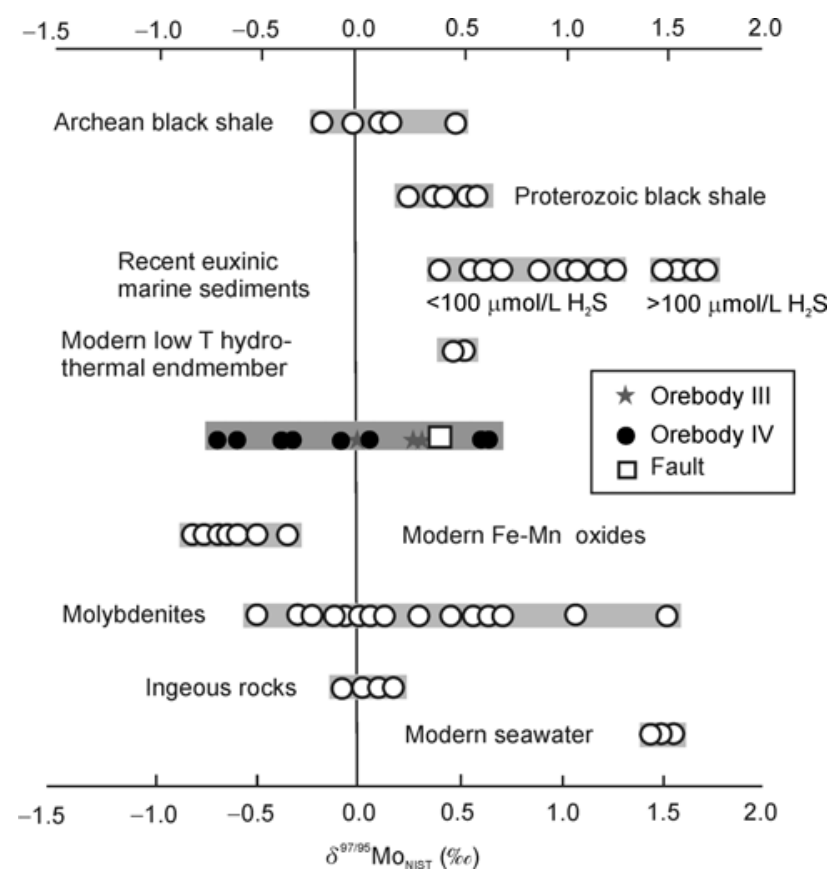

Figure 2 Distribution of molybdenum isotope of Dajiangping pyrite deposit compared with reported data $[4,6,14,17,18,29-33]$.
Dajiangping pyrite is relatively close to that of the hydrothermal molybdenite. The studies by McManus et al. [32] suggest that the $\delta^{97 / 95}$ Mo of modern submarine hydrothermal fluids is about $0.5 \%$, relatively different from the values of the orebodies. However, this difference may be ascribed to the variation between the modern and geological samples. For example, the $\delta^{97 / 95}$ Mo values of the Archean or Proterozoic black shales are less than modern seawater $\left(\delta^{97 / 95} \mathrm{Mo}=\sim 1.55 \%\right.$ ) and Arnold et al. [4] concluded that the $\delta{ }^{97 / 95} \mathrm{Mo}$ value of the seawater was approximately $0.8 \%$ in the Neoproterozoic period. Thus, the $\delta{ }^{97 / 95}$ Mo value may be less than $0.5 \%$ in the synchronous hydrothermal fluid and was likely close to the $\delta^{97 / 95}$ Mo values of the igneous rocks $(0-0.5 \%$ ) , based on the "Box Model" theory of Mo isotopes proposed by Anbar et al. [6]. Hence, an important conclusion is that the Mo isotopic composition of Orebody III with an average value of $0.18 \%$ in a narrow variation may reflect a homogeneous hydrothermal submarine source. In addition, Jiang et al. [34,35] suggested a similar perspective. The relatively homogeneous Mo isotopic composition of the Ni-Mo polymetallic sulfide bed in the Lower Cambrian Niutiang Formation in South China is also ascribed to submarine hydrothermal source. Furthermore, the published He-Ar isotopes of our previous work [25] also proved that the oreforming fluid of Orebody III was from submarine hydrothermal fluids. However, there is an apparent different Mo isotopic composition between Orebody III and IV in that the latter has a relatively broad range. It can be thus implied that the redox conditions of the ore-forming fluids from Orebody IV have changed or there may be great differences between Orebody III and IV in the metallogenic environment.

Various geochemical evidences have indicated that the metallogenic environment of Orebody IV is distinguished from Orebody III. First, the S isotopic composition was significantly different. Orebody III is homogeneous with light $\mathrm{S}$ isotope, while the $\mathrm{S}$ isotopic composition of Orebody IV is more dispersed. Second, the lead isotopic composition of Orebody III is in general consistent with the mining area 
layer, indicating a similar source. In contrast, the lead isotope values of Orebody IV imply a mixing source feature of formation $\mathrm{Pb}$ and basal $\mathrm{Pb}$, reflecting late hydrothermal alteration characteristics [20,22]. Third, the last and likely the most important evidence is fluid inclusion data. According to the microthermometry performed by Pan et al. [21] on gaseous fluid inclusions, the homogenization temperature of Orebody III ranges in $90-110^{\circ} \mathrm{C}$, consistent with the submarine hydrothermal temperature. However, the homogenization temperature of the fluid inclusions from Orebody IV is in the range $300-350^{\circ} \mathrm{C}$, reflecting a late hydrothermal superimposition. Therefore, the wider range of the $\delta^{97 / 95}$ Mo values in Orebody IV relative to those of Orebody III suggests that the Mo isotopic compositions of the Orebody IV ore-forming fluids might be related with the different Mo isotopic fractionation mechanism in the late hydrothermal superimposed metamorphism or late ore-forming hydrothermal systems. On the other hand, this also illustrates that the metallogenic environment of Orebody IV has undergone significant changes in the primary metallogenic stage.

The migration mechanism of Mo in oxygenated or anoxic water is dependent mainly the migration of Mn oxides and the particle reaction with the thiols $\left(\mathrm{MoO}_{4-x} \mathrm{~S}_{x}^{2-}\right)$ [3,5,6]. Anbar et al. [1] and Barling et al. [2] suggested that the Mo content has an obvious positive correlation with the Mo isotopes under an anoxic sedimentary environment, but once the redox conditions changed, these correlations no longer exist. As shown in Figure 3, a strong correlation $\left(R^{2}=0.88\right)$ is observed between the $\delta^{97 / 95}$ Mo values and Mo content of the three samples from Orebody III and one carbonaceous slate sample from the upper part of Orebody IV. In contrast, the correlation is fairly poor with $R^{2}=$ 0.22 , with respect to the samples from the lower part of Orebody IV (excluding the fault sample). Thus, it implies different sedimentary environment between the two orebodies. We tentatively inferred that the metallogenic environment of Orebody III is relative anoxic, while the metallogenic environment of Orebody IV was more oxidized or

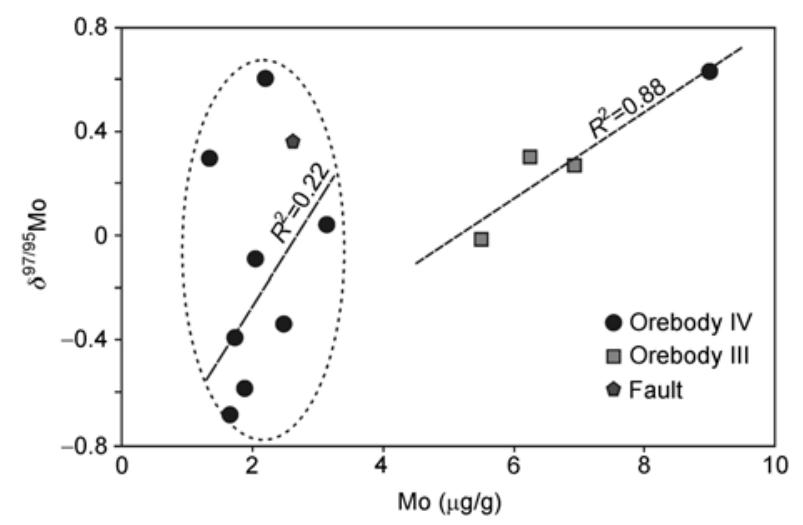

Figure 3 Correlation of Mo contents and Mo isotopic compositions of the Dajingping pyrite deposit. under a suboxic metallogenic environment. The similar feature has been observed in the study on the Mo isotopic compositions of black shale and Ni-Mo polymetallic sulfide bed in the Lower Cambrian Niutiang Formation in South China by Jiang et al. [34]. The Mo contents were highly correlated with the Mo isotopic compositions $\left(R^{2}=0.71\right)$. They proposed that this coupling might reflect a mixture of Mo from a seawater source (heavy Mo isotope feature) with the origin of the detrital shale Mo (light Mo isotope feature). Of course, this possibility could not be completely excluded here and requires further work.

The $\delta^{97 / 95}$ Mo values of five samples from the main ore-bed of Orebody IV are negative, especially for samples DJP4-7 and DJP4-9. They are even the lowest in the literatures of hydrothermal systems, similar to those of the modern ocean floor ferromanganese nodules $\left(-0.75 \% \%_{-}\right.$ $-0.26 \%$ o). However, until now, the Mo isotopic fractionation mechanism and its migration form in suboxic environment has not been clear sufficiently. A preliminary assumption was proposed that the ligand exchange $\left(\mathrm{MoO}_{4}^{2-}, \mathrm{MoO}_{4-x} \mathrm{~S}_{x}^{2-}\right)$ or reduction process $\left(\mathrm{Mo}^{6+} \rightarrow \mathrm{Mo}^{4+}\right)$ caused the Mo isotopic fractionation [6,36,37]. Furthermore, organic matter also influence the precipitation and fractionation of Mo [38-40]. Combined with observation by scanning electron microscopy (SEM) and electron probe microanalysis (EPMA) on Orebody IV, we infer that the enrichment of the light Mo isotope may be related to the following two factors:

(1) Microorganisms and organic matter: biological processes could lead to Mo isotopic fractionation. Nägler et al. [41] has investigated Mo isotopic fractionation using the nitrogen-fixing bacteria Trichodesmium sp. IMS101 in the Mo absorption process and found that nitrogen-fixing Trichodesmium tended to absorb light Mo isotopes with a $\delta{ }^{97 / 95}$ Mo value of $-0.3 \%$. They suggested that metal isotopic fractionation could be related to microbial species, types of Mo ingressing microorganisms and the Mo function in biological agent processes. Based on a comparison of the Mo isotope composition of the modern marine carbonatite with carboniferous carbonatite, Andrea et al. [42] also thought that biotic bacteria have a great effect on Mo isotopic fractionation. Fortin et al. [43] found a large number of filamentous bacteria and organic carbon collected from Philosopher hydrothermal vents surrounding the modern northeast Pacific. These filaments could have been mineralized filamentous bacteria and most of the bacteria mineralization and bacteria polymer peripherals were encased by silicon-rich iron oxide, manganese oxide and iron metasilicate. As discussed above and according to the Mo isotopic fractionation principle, these encased ferromanganese oxides should have a strong adsorption capacity towards light Mo isotopes. Here, we also found much vein-type apatite and filling organic matter using SEM observation in Orebody IV (Figure 4(a)), indicating that hydrothermal and biological activity were relatively strong during the Ore- 

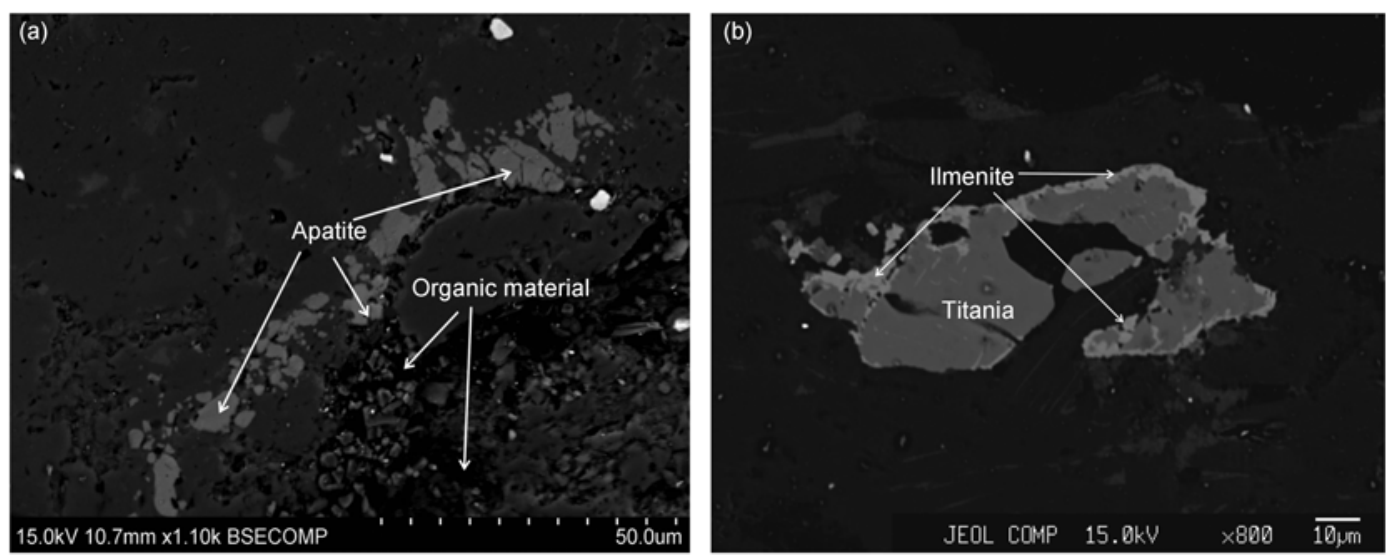

Figure 4 Backscattered electron images of orebody IV. (a) Apatite vein and filled organic matter; (b) replacement of titania by erromanganese phase ilmenite.

body IV formation. Chen et al. [44] and Wang et al. [45] also reported a large number of well-preserved algal fossils, mainly filamentous algae and symbiotic with the pyrite layer, suggesting that before the pyrite mineralized, massive algae were deposited. We speculate that these algae slowly release oxygen during photosynthesis to cause partial micro-oxidized environments which could oxidize its carrier or peripheral Fe-Mn compounds. These Fe-Mn compounds were oxidized and also adsorbed the light Mo isotopes at the same time. In other words, these algae might carry a number of light Mo isotopes. In addition the late inherited algae adsorbing the light Mo isotopes of the native algae may also lead to a light Mo isotopic fractionation yield, and brought into forming fluids in the late diagenetic stage. In addition, these organisms decomposed to organic matter with light Mo isotope retention. As organic matter decomposed in the late high temperature hydrothermal fluids, there is not enough space or capability to conserve the light Mo isotopes, which are released into the ore-forming fluid. It can also result in the negative Mo isotope values for Orebody IV.

(2) Replacement and adsorption of Fe-Mn oxides: redox condition changes may cause the alternation of elemental valence and coordination number, in turn leading to a variation in bond energy between atoms in the crystal lattice. During this alternation process isotopic fractionation can be generated by transition metal elements [46]. Balistrieri et al. [47] suggested that metal anionic groups, such as $\mathrm{MoO}_{4}^{2-}$, $\mathrm{H}_{4} \mathrm{GeO}_{4}^{-}$or $\mathrm{H}_{3} \mathrm{GeO}_{4}^{-}$adsorb light isotopes on the mineral surface in the adsorption process. Mathur et al. [18] found that the Mo isotopic fractionation of the molybdenite from the porphyry copper deposit had a rather smaller $\delta^{97 / 95} \mathrm{Mo}$ value relative to the skarn deposit. They inferred that the reason lead to Mo isotopic fractionations was different mineral facies adsorption in the metallogenic epoch. As Figure 4(b) shows, there is obvious Fe-Mn oxide metasomatic growth along the edge of the titania in later hydrothermal fluids in the Orebody IV flake. Generally, under oxidative conditions, Fe-Mn oxides alternate with titania according to the following reaction:

$$
\mathrm{MnO}_{2}+\mathrm{TiO}_{2} \rightarrow \mathrm{MnTiO}_{3}+1 / 2 \mathrm{O}_{2}
$$

$\mathrm{MnTiO}_{3}$ carries $\mathrm{MnO}_{6}$ anionic octahedra [48], which has relatively larger ion channels and space. As a result, light Mo isotope is easy to be adsorbed and preserved. Moreover, a small amount of oxygen ions releasing during the alternation process could further oxidize the Fe-Mn compound and adsorb light Mo isotope. It is another possible factor resulting in negative Mo isotopes in Orebody IV.

Although two of the mechanisms described above may to some extent explain the light isotope enrichment characteristics in Orebody IV, why some orebody samples located in the upper part of Orebody IV show heavy isotope enrichment characteristics needs to be considered. Assuming that the redox conditions of the metallogenic environment remain unchanged in an open system, the Mo isotope signal of the ore reserved should be so concordance that could not generate such a large Mo isotopic fractionation in the same orebody. In addition, the $\delta^{97 / 95}$ Mo values increase stratigraphically upward, excluding the possibility of isotopic composition changes derived from superimposition of late hydrothermal fluids for they have a relatively stable isotopic composition. Therefore, we inferred that such a large Mo isotopic fractionation resulted from a closed or semi-closed metallogenic environment. This hypothesis is supported by evidence from the $\delta^{34} \mathrm{~S}$ values of most of the sulfides (average $16.06 \%$ ), which indicates a similar metallogenic environment [20]. Under such an environment, the early precipitates prefer to capture light isotope and the residual fluids enrich with heavy isotopes because of Fe-Mn oxide adsorption or biological matter effect. As the mineralization proceeds, the residual fluids increasingly remain more heavy isotopes and those precipitation samples gradually show the heavy isotopic characteristics compared to previous features. During this sedimentation, there exist the effects of dynamic fractionation. Therefore, the metallogenic environment of Orebody IV is different from open oceanic 
systems, where there might be a certain degree of dynamic fractionation. This has wide implications for the study of Mo isotopic fractionation in the restricted basin fluids.

\section{Conclusions}

(1) There are different Mo isotopic composition characteristics between Orebody III and IV in the Dajiangping pyrite deposit. The $\delta^{97 / 95}$ Mo geological significance of Orebody III indicates that the ore-forming fluids are derived from submarine exhalative hydrothermal fluids, while Orebody IV may have also been influenced by hydrothermal superimposition. This is consistent with other geochemical evidence.

(2) Orebody III is likely deposited under a relatively open and strong biological agent reducing environment, while Orebody IV may be formed in a closed to semi-closed restricted system that was in suboxic-oxic disequilibrium condition. Dynamic Mo isotopic fractionation can be present in this restricted environment.

(3) Mo isotopes can be used as an effective tracer to study ore-forming fluids and metallogenic environments.

The authors thank Dr. Yao Chang from the State Key Laboratory for Mineral Deposits Research at Nanjing University and Dr. Wang Ying from Purple Mountain Observatory, Chinese Academy of Sciences at Nanjing for their technical support. Thanks are also due to Peng Naixiong for the field work. The paper has benefited greatly from the suggestions of anonymous reviewers and constructive comments from the associate editor. This work was supported by the National Natural Science Foundation of China (40638042, 40572056, 40873014 and 40930425) and the "West Light" of the Chinese Academy of Sciences.

1 Anbar A D, Knab K A, Barling J. Precise determination of mass-dependent variations in the isotopic composition of molybdenum using MC-ICP-MS. Anal Chem, 2001, 73: 1425-1431

2 Barling J, Arnold G L, Anbar A D. Natural mass dependent variations in the isotopic composition of molybdenum. Earth Planet Sci Lett, 2001, 193: 447-457

3 Siebert C, Nagler T F, Von Blanckenburg F, et al. Molybdenum isotope records as a new potential new proxy for paleoceanography. Earth Planet Sci Lett, 2003, 211: 159-171

4 Arnold G L, Anbar A D, Barling J, et al. Molybdeum isotope evidence for widespread anoxia in Mid-Proterozoic oceans. Science, 2004, 304: 87-90

5 Anbar A D. Molybdenum stable isotopes: Observations, interpretations and directions. Rev Mineral Geochem, 2004, 55: 429-454

6 Anbar A D, Rouxel O. Metal stable isotopes in Paleo-oceanogarphy. Ann Rev Earth Planet Sci, 2007, 35: 717-746

7 Zhou L, Gao S, Chris H. Preliminary Mo isotope data of Phanerozoic clastic sediments from the northern margin of the Yangtze block and its implication for paleoenvironmental conditions. Chinese Sci Bull, 2009, 54: 822-829

8 Nadja N, Thomas F, Michael E. Sulfidity controls molybdenum isotope fractionation into euxinic sediments: Evidence from the modern Black Sea. Geology, 2008, 36: 775-778

9 Wen H J, Zhang Y X, Fan H F, et al. Mo isotopes in the lower Cambrian formation of southern China and its implications on paleo-ocean environment. Chinese Sci Bull, 2009, 54: 4756-4762

10 Ryb U, Erel Y, Matthews A, et al. Large molybdenum isotope varia- tions trace subsurface fluid migration along the Dead Sea transform. Geology, 2009, 37: 463-466

11 Collier R W. Molybdenum in the northeast Pacific Ocean. Limnol Oceanogr, 1985, 30: 1351-1354

12 Morris A W. Dissolved molybdenum and vanadium in the northeast Atlantic Ocean. Deep-Sea Res, 1975, 22: 49-54

13 Emerson S R, Huested S S. Ocean anoxia and the concentrations of molybdenum and vanadium in seawater. Mar Chem, 1991, 34: 177196

14 Barling J, Anbar A D. Molybdenum isotope fractionation during adsorption by manganese oxides. Earth Planet Sci Lett, 2004, 217: 315329

15 Wasylenki L E, Rolfe B A, Week C L, et al. Experimental investigation of the effects of temperature and ionic strength on Mo isotope fractionation during adsorption to manganese oxides. Geochim Cosmochim Acta, 2008, 72: 5997-6005

16 Neubert N, Naegler T F, Boettcher M E. Sulfidity controls molybdenum isotope fractionation into euxinic sediments: Evidence from the modern Black Sea. Geology, 2008, 36: 775-778

17 Hannah J L, Stein H J, Wieser M E, et al. Molybdenum isotope variation in molybdenite: Vapor transport and Rayleigh fractionation of Mo. Geology, 2007, 35: 703-706

18 Mathur R, Brantley S, Anbar A D, et al. Variation of Mo isotopes from molybdenite in high-temperature hydrothermal ore deposit. Miner Deposit, 2009, 45, doi: 10.1007/s00126-009-0257-z

19 Zhang Q, Zhang B G, Pan J Y, et al. Silicalite characteristics and rareearth element model of Dajiangping pyrite deposit in western Guandong Province (in Chinese). Chinese Sci Bull, 1992, 37: 1588-1592

20 Zhang Q, Zhang B G, Cao Y B, et al. Preliminary discussion on sulfur and lead isotope compositions of the dajingping pyrite deposite in western Guangdong Province (in Chinese). Acta Geol Sin, 1993, 67: 232-243

21 Pan J Y, Zhang Q, Zhang B G. A preliminary discussion on geochemical characteristics and gensis of the Dajingping pyrite deposit, western Guangdong (in Chinese). Geol Prosp, 1994, 13: 231-241

22 Chen D F, Ma S G, Dong W Q, et al. Pb and Nd isotopes of the Dajiangping pyrite deposit, Guangdong Province, and its metallic ore source (in Chinese). Mineral Deposit, 1998, 17: 215-223

23 Chen D F, Chen G Q, Pan J M, et al. Characteristics of the hyprothermal sedimentation of the Dajingping superlarger pyrite deposit in Yunfu, Guangdong (in Chinese). Geochimica, 1998, 27: 12-19

$24 \mathrm{Li} \mathrm{K}, \mathrm{Hu} \mathrm{K}$, Jiang S Y, et al. Geochemical characteristics of $\mathrm{He}-\mathrm{Ar}$ isotopes and Rare earth elements in the Dajiangping pyrite deposit in western Guangdong, South China (in Chinese). J Nanjing Univ, 2006. 42: 611-620

25 Yang R Y, Cao J J, Kang X G, et al. The characteristics and genesis of Yunfu pyrite deposit in Guangdong Province (in Chinese). Acta Sci Nat Univ Sunyat, 1997, 36: 79-84

26 Wang H N, Li H Y, Wang Y X, et al. Rb-Sr isotope dating of silicalite from the Dajiangping massive sulfide ore deposit, Guangdong Province. Chinese Sci Bull, 1997, 42: 1983-1985

27 Zhang Y X, Wen H J, Fan H F. Chemical pretreatment methods for measurement for Mo isotope ratio on geological samples (in Chinese). Chin J Anal Chem, 2009, 37: 356-363

28 Wen H J, Carignan J, Cloquet C, et al. Isotopic delta values of molybdenum standard reference and prepared solutions measured by MC-ICP-MS: Proposition for delta zero and secondary references. J Anal Atom Spect, 2010, 25: 716-721

29 Poulson R L, Siebert C, McManus J, et al. Authigenic molybdenum isotope signatures in marine sediments. Geology, 2006, 34: 617620

30 Pietruszka A J, Walker R J, Candela P A. Determination of mass-dependent molybdenum isotopic variations by MC-ICP-MS: An evaluation of matrix effects. Chem Geol, 2006, 225: 121-36

31 Malinovsky D, Hammarlund D, Ilyashuk B, et al. Variations in the isotopic composition of molybdenum in freshwater lake systems. Chem Geol, 2007, 236: 181-198 
32 McManus J, Nagler T F, Siebert C, et al. Oceanic molybdenum isotope fractionation: Digenesis and hydrothermal ridge-flank alteration. Geochem Geophys Geosyst, 2002, doi: 10.1029/2002GC000356

33 Nägler T F, Siebert C, Luschen H, et al. Sedimentary Mo isotope record across the Holocene fresh-brackish water transition of the Black Sea. Chem Geol, 2005, 219: 283-295

34 Jiang S Y, Ling H F, Zhao K D, et al. A discussion on Mo isotopic composition of black shale and Ni-Mo sulfide bed in the early Cambrian Niutitang Formation in south China (in Chinese). Acta Petrol Miner, 2008, 27: 341-345

35 Jiang S Y, Pi D H, Heubeck C, et al. Early Cambrian ocean anoxia in South China. Nature, 2009, 459: E5-E6

36 Siebert C, Mcmaunus J, Bice A, et al. Molybdenum isotope signatures in continental margin marine sediments. Earth Planet Sci Lett, 2006, 241: 723-733

37 Poulson R L, Siebert C, McManus J, et al. Authigenic molybdenum isotope signatures in marine sediments. Geology, 2006, 34: 617-620

38 Wilde P, Lyons T W, Quinby-Hunt M S. Organic carbon proxies in black shales: molybdenum. Chem Geol, 2004, 206: 167-176

39 Malinovsky D, Rodushkin I, Baxter D C, et al. Molybdenum isotope ratio measurements on geological samples by MC-ICP-MS. Int J Mass Spect, 2005, 245: 94-107

40 Zhou L, Zhou H B, Li M, et al. Molybdenum isotope signatures from Yangtze Craton Continental Margin and its indication to organic burial rate (in Chinese). Earth Sci-J Chin Univ Geosci, 2007, 32: 759-
766

41 Nägler T F, Mills M M, Siebert C. Biological fractionation of Mo isotopes during N-2 fixation by Trichodesmium sp. IMS 101. Geochim Cosmochim Acta, 2004, 68(Suppl): A364

42 Andrea R V, Thomas F N, Elias S, et al. Molybdenum isotopic composition of modern and carboniferous carbonates. Chem Geol, 2009, 265: 488-498

43 Fortin D, Ferris F G, Scott S D. Formation of Fe-silicates and Fe-oxides on bacterial surfaces in samples collected near hydrothermal vents on the Southern Explorer Ridge in the northeast Pacific Ocean. Amer Mineral, 1998, 83: 1399-1408

44 Chen Z Q, Wang H N, Li H Y. The discovery of fossil algre in the pyritic ore beds of Dajiangping, Guangdong, and its geological significance (in Chinese). J Nanjing Univ, 1992, 4: 82-85

45 Wang $\mathrm{H} \mathrm{N}$, Li H Y. Late Proterozoic microfossils from exhalitesediment massive pyrite deposits, South China. IGC, Beijing, 1996, 568

46 Jiang S Y. Transition metal isotopes: Analytical methods and geological applications (in Chinese). Earth Sci Front, 2003, 10: 269-279

47 Balistrieri L S, Borrok D M, Wanty R B, et al. Fractionation of Cu and $\mathrm{Zn}$ isotopes during adsorption onto amorphous $\mathrm{Fe}(\mathrm{III})$ oxy-hydroxide: Experimental mixing of acid rock drainage and ambient river water. Geochim Cosmochim Acta, 2008, 72: 311-328

48 Zhou G W, Kang Y S. Synthesis and structural properties of manganese titanate $\mathrm{MnTiO}_{3}$ nanoparticle. Mater Sci Eng C, 2004, 24: 71-74

Open Access This article is distributed under the terms of the Creative Commons Attribution License which permits any use, distribution, and reproduction in any medium, provided the original author(s) and source are credited. 